\title{
Effect of a physical exercise program on plasma concentration of adiponectin in overweight and obese children
}

Efeito de um programa de exercícios físicos na concentração plasma de adiponectina em crianças com sobrepeso e obesidade

Efecto de un programa de ejercicio físico sobre la concentración plasmática de adiponectina en niños con sobrepeso y obesidad

Mariana Marcolino Costa ORCID: https://orcid.org/0000-0002-2992-5766 Federal University of São João del Rei, Brazil E-mail: marianamarcolinocosta@gmail.com.br

André Everton de Freitas ORCID: https://orcid.org/0000-0001-9039-3853 Centro Universitário UNIDAVI, Brazil E-mail: aefreitas13@gmail.com

Danusa Dias Soares

ORCID: https://orcid.org/0000-0002-5705-8890 Federal University of Minas Gerais, Brazil E-mail: danusa56@gmail.com

Thiago Henrique Oliveira ORCID: https://orcid.org/0000-0003-1175-0184 Federal University of Minas Gerais, Brazil E-mail: oliveirathenrique@gmail.com

Débora Romualdo Lacerda

ORCID: https://orcid.org/0000-0003-1917-8944 Federal University of Minas Gerais, Brazil E-mail: deboraromualdo.lacerda@gmail.com Joyce Batista Andrade ORCID: https://orcid.org/0000-0002-6629-1758 Federal University of Minas Gerais, Brazil E-mail: joycebatista13@yahoo.com.br

Adaliene Versiani Matos Ferreira ORCID: https://orcid.org/0000-0003-2256-8652

Federal University of Minas Gerais, Brazil E-mail: adaliene@gmail.com

Vinícius Oliveira Damasceno ORCID: https://orcid.org/0000-0003-0577-9204 Federal University of Minas Gerais, Brazil E-mail: vinicius.damasceno@ufpe.br Joel Alves Lamounier ORCID: https://orcid.org/0000-0002-8386-4140 Federal University of São João del Rei, Brazil E-mail: lamounierjoel@gmail.com

\begin{abstract}
Adiponectin is considered a biomarker of health status, and high levels are associated with good health. Science discusses the results on the effects of physical activity on increasing adiponectin levels, especially in child with obesity. The scope of the present study was to evaluate a physical exercise intervention program, after 10 months of duration, in the plasma concentration of adiponectin in students from six to nine years of age with overweight and obesity. This is a randomized clinical study of a near-experimental intervention of the type before and after. The physical exercise resulted in a significant reduction in the percentage of body fat $(\% \mathrm{BF})$ and triglycerides. Adiponectin there was a nonsignificant increase. The present study showed that the practice of physical exercise did not increase adiponectin levels, but was responsible for a great improvement in the children lipid profile and reduction in \%BF.
\end{abstract}

Keywords: Adiponectin; Obesity; Overweight; Children; Exercise. 


\section{Resumo}

A adiponectina é considerada um biomarcador do estado de saúde, e níveis elevados estão associados à boa saúde. A ciência discute os resultados sobre os efeitos da atividade física no aumento dos níveis de adiponectina, principalmente em crianças com obesidade. O objetivo do presente estudo foi avaliar um programa de intervenção de exercício físico, após 10 meses de duração, na concentração plasmática de adiponectina em escolares de seis a nove anos de idade com sobrepeso e obesidade. Trara-se de um estudo clínico randomizado de intervenção quase experimental do tipo antes e depois. O exercício físico resultou em redução significativa no percentual de gordura corporal (\%GC) e triglicerídeos. Houve um aumento não significativo para adiponectina. O presente estudo mostrou que a prática de exercício físico não aumentou os níveis de adiponectina, mas foi responsável por uma grande melhora no perfil lipídico das crianças e redução do \%GC.

Palavras-chave: Adiponectina; Obesidade; Sobrepeso; Crianças; Exercício.

\section{Resumen}

La adiponectina se considera un biomarcador del estado de salud y los niveles altos se asocian con una buena salud. La ciencia discute los resultados sobre los efectos de la actividad física en el aumento de los niveles de adiponectina, especialmente en niños con obesidad. El objetivo del presente estudio fue evaluar un programa de intervención de ejercicio físico, después de 10 meses de duración, en la concentración plasmática de adiponectina en escolares de seis a nueve años con sobrepeso y obesidad. Métodos. Este es un estudio clínico aleatorizado de una intervención casi experimental del tipo antes y después. Resultados. El ejercicio físico resultó en una reducción significativa del porcentaje de grasa corporal (\%GC) y triglicéridos. Adiponectina hubo un aumento no significativo. Conclusión. El presente estudio mostró que la práctica de ejercicio físico no aumentó los niveles de adiponectina, pero fue responsable de una gran mejoría en el perfil lipídico de los niños y una reducción del \%GC.

Palabras clave: Adiponectina; Obesidad; Sobrepeso; Niños; Ejercicio.

\section{Introduction}

Obesity can be understood as a metabolic disorder characterized by chronic inflammatory status and excessive accumulation of fat in adipose tissue (AT), with increased body mass and negative impact on health (Paim et al., 2020). In 2019, according to information from the Food and Nutritional Surveillance System, $28.1 \%$ of children between five and nine years old, followed up in Primary Care, were overweight; $13.2 \%$ of them were obese. Considering all Brazilian children under 10 years of age, it is estimated that about 6.2 million are overweight and 2.9 million are obese (Brasil, 2020).

Some of the main consequences of obesity, both in childhood and adulthood, are related to a higher risk for chronic non-communicable diseases (NCDs), such as cardiovascular complications, systemic arterial hypertension (SAH), atherosclerosis, dyslipidemias, type two diabetes mellitus (DM 2) and orthopedic complications (musculoskeletal) (WHO, 2020; Mendonça et al., 2020). In addition, there are numerous emotional and psychosocial problems, such as bullying, low self-esteem, depression and reduction in school attendance (Mendonça et al., 2020).

Evidence indicates that obesity has a causal relationship with a low-grade chronic inflammatory state, and this is because AT synthesizes and secretes bioactive substances, such as adipocins, which are elevated in obese individuals. The unregulated expression of these factors, caused by excess adiposity and dysfunction of adipocytes, has been associated with the pathogenesis of several diseases. Plasma adiponectin concentrations are negatively correlated with visceral fat accumulation (Martínez-Hernández et al., 2019; Liaw et al., 2016; Romano, 2010). Some of the functions of adiponectin include decreased serum glucose levels and reduced insulin resistance (IR), regulation of energy balance, acts on the hypothalamus in the control of hunger and thermogenesis; in addition to antiatherogenic, anti-inflammatory, antihypertensive and antioncogenic functions. Thus, adiponectin is considered a biomarker of health status (Díaz et al., 2018; García-Hermoso et al., 2017; Liaw et al., 2016; Romano, 2010).

High levels of adiponectin are associated with good health; however, this fact is not constant among the different investigations. Science discusses the results on the effects of physical activity on increasing adiponectin levels, especially in children. Meta-analysis studies and systematic review of randomized clinical trials that evaluated the outcome of physical exercise, adiponectin and pediatric obesity, pointed out that exercise was associated with a significant increase in adiponectin 
(Sirico et al., 2018; García-Hermoso et al., 2017; Jamurtas et al., 2015). On the other hand, inconsistent results have been reported in the pediatric population, with no elevation of adiponectin after a physical activity program (Jadhav et al., 2021; Bouassida et al., 2010; Simpson \& Singh, 2008; Direcnet, 2008; Kelly et al., 2007).

Based on this evidence, in a scenario with an increasing prevalence of childhood obesity and its health repercussions, the present study aimed to evaluate a physical exercise intervention program, after 10 months of duration, in the plasma concentration of adiponectin in students from six to nine years of age with overweight and obesity.

\section{Methodology}

\subsection{Study design}

This is a randomized clinical study of a near-experimental intervention of the type before and after, blind, aiming to evaluate the evolution of a physical exercise intervention program in plasma concentration of adiponectin, in overweight and obese children, at baseline and after ten months.

\subsection{Inclusion and exclusion criteria}

The inclusion criteria adopted were: overweight and obese children enrolled in a public institution located in the urban area of Ouro Preto, belonging to the age group between six and nine years old, attending the first to fifth grade of elementary school, in morning or afternoon shifts. Exclusion criteria were: children who had chronic diseases, in order to promote more homogeneity of the sample and minimize health risk; schools with less than 200 students and night time classes.

\subsection{Population group}

The study was conducted with students enrolled from the first to fifty grade of elementary school from seven public educational institutions in the urban area of Ouro Preto, Minas Gerais, totaling 1,564 students, according to data provided by the Municipal Department of Education and schools' registration. Of these, 1,019 who were between six and nine years old, comprised the baseline sample (Step 1). The children were measured and weighed to calculate body mass index (BMI) and characterized for body composition in eutrophic, overweight or obesity (Freitas et al., 2007). All overweight and obese children $(n=119)$ were invited to participate in the intervention study and the final sample consisted of 79 children whose parents and/or guardians authorized their participation, since 40 children did not want to participate in the study. The children were randomly and unconsciously distributed in two groups, one intervention (A) and the other control (B). At the end of 10 months of intervention, all children had their evolution evaluated (Step 2). The FIG. 1 flowchart illustrates the steps involved: 
Figure 01 - Distribution of children into groups: intervention (A) and control (B).

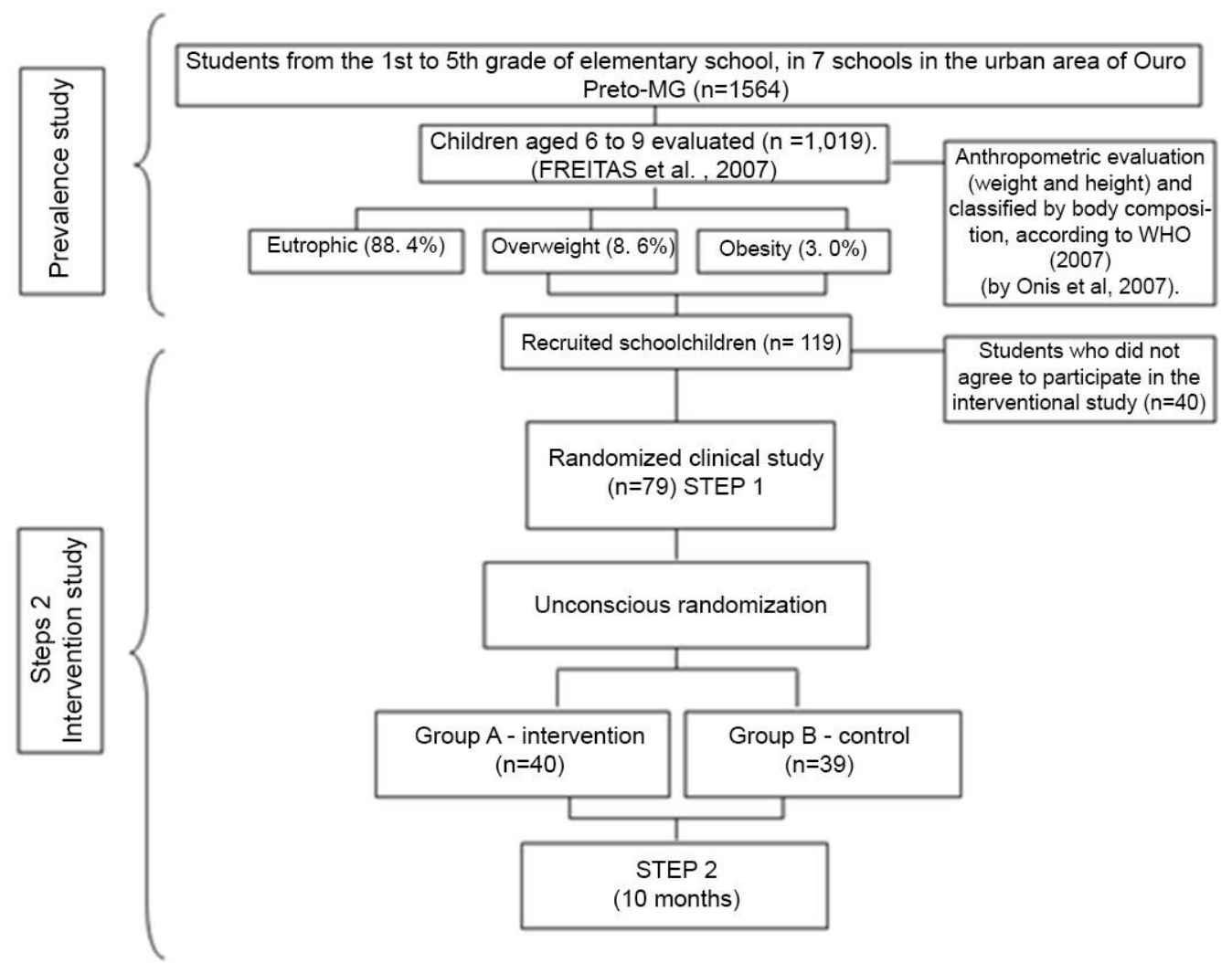

Source: Authors.

All children from both groups (control and intervention) were submitted to an initial evaluation where data were collected on the parameters body composition, clinical profile, laboratory and biochemical. All activities were carried out by health professionals previously trained regarding the collection and analysis procedures, following a protocol for standardization of procedures. The intervention program, lasting 10 months, was carried out during the school year of 2008. The choice of the moment of analysis adopted, after 10 months of intervention, was according to the periods of school recess. All selected individuals were part of an intervention program developed as follows:

-Group A (intervention): the children allocated were submitted to a physical exercise program, three times a week, in the afternoon, lasting 50 minutes, during the school period for 10 months (February to November), except during the school recess period. The activities consisted of playful games, races and jumps and collective games, held in a covered gym of the Sports Center of the Federal University of Ouro Preto (UFOP). Monthly educational lectures were also given to parents and children, regarding healthy eating habits, physical exercise and family relationships, during 10 months (except school recess), two monthly lectures, one for parents and one for children, totaling 16 activities.

-Group B (control): the children and parents were submitted to the same program of educational lectures proposed for the intervention group. The topics addressed were healthy eating habits, physical exercise and family relationships, over 10 months (except school recess), two monthly lectures, one for parents and one for children, totaling 16 activities. The activities of the lectures consisted of workshops and educational work in nutrition, to stimulate the consumption of healthy foods; reduction of high-fat and calorie food intake; promotion of healthy habits to reduce physical inactivity, with the purpose of reducing the number of hours of computer screen, video games, etc., and stimulate the increase of physical exercise by the practice of individual and collective sports. 


\subsection{Variables and measures}

The variables studied were: body composition (weight and height for BMI calculation; triipital and calf skinfolds to assess body fat percentage; waist circumference (WC) and hip circumference); laboratory variables (lipid profile - total cholesterol (TC) and triglycerides (TG) and fasting glycemia of 12 hours); biochemical variable (plasma concentration of adiponectin).

The Z-score by BMI age was used to determine the nutritional status of the participants, proposed by the WHO and categorized in both moments of data collection according to gender and changes in age (WHO, 2020). Plasma adiponectin concentration was determined by ELISA with the Adiponectin Human ELISA kit (catalogue number: EZHADP-61K), according to the manufacturer's recommendations.

\subsection{Statistical analysis}

The data were analyzed by analysis of treatment intention. Blind and unconscious allocation were also adopted. All numerical variables were described with mean, median, standard deviation, minimum and maximum. The Shapiro-Wilk test was used to evaluate the normality of the distribution of variables. The results of this test were used as criteria for the choice of statistical tests for the comparison between the control and intervention groups (independent samples), as well as for the comparison in the intervention group before and after the physical activity program (paired samples). The results of the statistical tests are described with the differences between the groups and their respective $95 \%$ confidence intervals, as well as with the probability value $(\mathrm{P})$.

The comparison of quantitative variables in the same group was made by paired Student's $\mathrm{T}$ test (parametric) or Wilcoxon test (nonparametric). The comparison of quantitative variables between groups was made by the $\mathrm{T}$ test, for independent samples (parametric), or by the Man Whitney U test (nonparametric). Pearson's exact Chi-square test was performed to compare the variable BMI categorized between the intervention and control groups. Where there was statistical significance, the analysis of standardized adjusted residuals was performed to show where the difference was.

2.6 Ethical considerations

The study worked on data from an experimental study conducted in 2008, approved by the Ethics and Research Committee of UFMG according to ETIC 471/06. All parents or guardians of the children signed the Informed Consent Form (TCLE).

\section{Results}

The studied group consisted of 40 boys (50.6\%) and 39 girls (49.4\%). At baseline, the median age was 8 years. In the characterization of individuals, comparing means and medians before the exercise incentive program and after intervention, weight, height, body fat percentage (\%BF) and BMI (body mass index) increased in the comparison between steps 1 and 2. Regarding laboratory findings, blood glucose decreased, while total cholesterol, triglycerides and adiponectin increased (Table 1). 
Table 1 - Characterization of individuals before the incentive program for exercise and after intervention: frequencies, means $($ mean \pm d) and medians (median $(\mathrm{Q} 1 ; \mathrm{Q} 3))($ Steps 1 and 2) $(\mathrm{n}=79)$.

\begin{tabular}{lll}
\hline Variables & Step 1 & Step 2 \\
\hline Sex & & -- \\
Male & $40(50,6)$ & -- \\
Female & $39(49,4)$ & -- \\
Age in years & $8,00(7,00 ; 9,00)$ & $42.17 \pm 8.88$ \\
Weight & $36,90(31,30 ; 41,90)$ & $139.40 \pm 7.55$ \\
Height in cm & $133.40 \pm 8.03$ & $27.77 \pm 8.42$ \\
\%GC & $30.77 \pm 6.17$ & $21.55 \pm 3.13$ \\
BMI (n=79 and 75) & $20,29(18,99 ; 23,00)$ & \\
BMI categorization & & $6(8,0)$ \\
Normal & $0(0,0)$ & $23(30,7)$ \\
Overweight & $33(41,8)$ & $46(61,3)$ \\
Obese & $46(58,2)$ & $31.03 \pm 7.13$ \\
Brachial and Sural triceps in cm & $33.70 \pm 6.78$ & $74.62 \pm 9.34$ \\
Waist in cm & $72.96 \pm 9.35$ & $82.27 \pm 7.80$ \\
Hip in cm & $81.63 \pm 8.02$ & $29.63 \pm 2.08$ \\
Neck in cm & $30.03 \pm 1.99$ & $90.52 \pm 4.88$ \\
Waist/Hip & $89.94 \pm 7.05$ & $79,73(75,16 ; 83,85)$ \\
Blood glucose (n=74 and 72) & $94,22(66,34 ; 100 ; 36)$ & $146.66 \pm 22.70$ \\
Total cholesterol (n=73 and 72) & $126.91 \pm 29.79$ & $90,60(70,07 ; 108,46)$ \\
Triglycerides (n=73 and 72$)$ & $77,59(48,04 ; 107,02)$ & $32,09+11,33$ \\
Adiponectin (n=62 and 46) & $25,88(20,20 ; 37,24)$ & \\
\hline
\end{tabular}

$\% \mathrm{BF}=$ body fat; $\mathrm{BMI}=$ body mass index; distribution verified by Shapiro-Wilk. Source: Authors.

In the intervention group in the comparison of Steps 1 and 2 (Table 2), a statistically significant difference was observed at the level of $5 \%(\mathrm{p}<0.05)$, the median weight and the mean height and waist circumference, which were higher in Step 2 compared to Step 1; while the means of fat percentage and the measurement of Brachial and Sural Triceps, and the median triglycerides, were lower in Step 2 compared to Step 1.

For the control group, in the comparison of quantitative and categorical variables of the data between Steps 1 and 2 (Table 3), the results that showed a statistically significant difference at the level of 5\% ( $<<0.05)$ were the mean weight, height, waist and hip, and the median BMI, total cholesterol and triglycerides, that were higher in Step 2 compared to Step 1; while the mean percentage of fat and Triceps Brachial and Sural and median glycemia were lower in Step 2 compared to Step 1. 
Table 2 - Comparison of the variables of the intervention group: comparison of means (mean $\pm \mathrm{d})$ and medians (median (Q1; Q3)) (Steps 1 and 2) (n=40)

\begin{tabular}{llll}
\hline Variables & Step 1 & Step 2 & $\begin{array}{l}\text { P-value comparison } \\
\text { Step 1 with Step 2 }\end{array}$ \\
\hline Weight & $\mathbf{3 9 , 2 8}(\mathbf{3 3 , 9 3 ;} \mathbf{4 4 , 8 3 )}$ & $\mathbf{4 4 , 1 0}(\mathbf{3 4 , 2 5 ; 4 9 , 2 5 )}$ & $<\mathbf{0 , 0 0 1 * *}$ \\
\hline Height in cm & $\mathbf{1 3 4 . 6 0 \pm 8 . 4 5}$ & $\mathbf{1 3 9 . 6 4} \pm \mathbf{7 . 6 4}$ & $<\mathbf{0 , 0 0 1 *}$ \\
\hline \%GC & $\mathbf{3 2 . 5 8} \pm \mathbf{6 . 3 4}$ & $\mathbf{2 9 . 3 7} \pm \mathbf{8 . 6 2}$ & $\mathbf{0 , 0 0 3} *$ \\
\hline BMI & $21,35(19,86 ; 24,26)$ & $21,76(19,26 ; 24,90)$ & 0,428 \\
\hline $\begin{array}{l}\text { Brachial and Sural } \\
\text { triceps in cm }\end{array}$ & $\mathbf{3 4 . 2 8} \pm \mathbf{7 . 2 3}$ & $\mathbf{3 1 . 1 9} \pm 7.73$ & $<\mathbf{0 , 0 0 1 *}$ \\
\hline Waist in cm & $\mathbf{7 5 . 3 5} \pm \mathbf{1 0 . 3 7}$ & $\mathbf{7 6 . 6 2} \pm \mathbf{1 0 . 2 6}$ & $\mathbf{0 , 0 3 0}$ \\
\hline Hip in cm & $83.68 \pm 9.47$ & $83.45 \pm 9.17$ & 0,540 \\
\hline Neck in cm & $30,40(28,68 ; 32,00)$ & $30,40(28,00 ; 31,50)$ & 0,993 \\
\hline Waist/Hip & $89.97 \pm 6.00$ & $91.65 \pm 4.59$ & 0,113 \\
\hline Glucose & $67,22(64,55 ; 95,14)$ & $80,38(76,14 ; 85,27)$ & 0,647 \\
\hline Total cholesterol & $143.43 \pm 19.67$ & $144.60 \pm 21.52$ & 1,000 \\
\hline Triglycerides & $\mathbf{1 0 0 , 4 5}(\mathbf{8 3 , 3 3 ; 1 2 6 , 6 5 )}$ & $\mathbf{9 0 , 6 0}(\mathbf{7 0 , 0 7} ; \mathbf{1 0 8 , 4 6 )}$ & $\mathbf{0 , 0 2 6} * *$ \\
\hline Adiponectin & $29,91(22,36 ; 40,82)$ & $31,96(22,65 ; 39,166)$ & 0,498 \\
\hline
\end{tabular}

$\% \mathrm{BF}=$ body fat; $\mathrm{BMI}=$ body mass index; *Paired Student $\mathrm{T}$ test; $*$ Wilcoxon Test. Source: Authors.

Table 3 - Comparison of control group variables: comparison of means (mean \pm d) and median (median (Q1; Q3)) (Steps 1 and 2) $(n=39)$.

\begin{tabular}{|c|c|c|c|}
\hline Variables & Step 1 & Step 2 & $\begin{array}{l}\text { P-value comparison } \\
\text { Step } 1 \text { with Step } 2\end{array}$ \\
\hline Weight & $34.91 \pm 5.69$ & $40.67 \pm 6.95$ & $<0,001 *$ \\
\hline Height in cm & $132.15 \pm 7.48$ & $139.18 \pm 7.56$ & $<0,001 *$ \\
\hline$\% \mathrm{GC}$ & $28.92 \pm 5.49$ & $26.21 \pm 8.04$ & $0,001 *$ \\
\hline BMI & $19,59(18,70 ; 20,53)$ & $20,70(19,90 ; 21,99)$ & $<0,001 * *$ \\
\hline $\begin{array}{l}\text { Brachial and Sural } \\
\text { triceps in } \mathrm{cm}\end{array}$ & $33.11 \pm 6.32$ & $30.88 \pm 6.61$ & $<0,001 *$ \\
\hline Waist in cm & $70.50 \pm 7.52$ & $72.68 \pm 8.00$ & $0,034 *$ \\
\hline Hip in cm & $79.52 \pm 5.57$ & $81.13 \pm 6.10$ & $0,001 *$ \\
\hline Neck in $\mathrm{cm}$ & $29.65 \pm 1.59$ & $29.44 \pm 1.63$ & 0,180 \\
\hline Waist/Hip & $89,27(86,06 ; 92,00)$ & $88,13(85,02 ; 93,91)$ & 0,597 \\
\hline Glucose & $97,47(94,22 ; 101,90)$ & $79,93(75,96 ; 84,61)$ & $<0,001 * *$ \\
\hline Total cholesterol & $102,89(92,59 ; 130,01)$ & $148,78(131,50 ; 182,70)$ & $<0,001 * *$ \\
\hline Triglycerides & $49,33(38,66 ; 62,10)$ & $84,41(59,18 ; 117,52)$ & $\mathbf{0 , 0 0 1 * *}$ \\
\hline Adiponectin & $23.02 \pm 11.74$ & $32.00 \pm 13.14$ & 0,061 \\
\hline
\end{tabular}

$\% \mathrm{BF}=$ body fat; $\mathrm{BMI}=$ body mass index; *Paired Student $\mathrm{T}$ test; **Wilcoxon Test. Source: Authors.

In the comparison between the groups, an analysis of the difference between the variables was performed in the comparison of the control and intervention groups (Table 4), the results that showed a statistically significant difference at the level of $5 \%(\mathrm{p}<0.05)$ were the means of the difference in weight and triglycerides and the median difference of BMI, Total Cholesterol and Adiponectin, who were larger in the control group than in the intervention group; while the median blood glucose difference was lower in the control group than in the intervention group. In the stratified analysis in the comparison of the differences between the boys x girls groups (Table 5), a significant difference was observed with a 95\% confidence interval $(\mathrm{p}<0.05)$ between the female and male groups in the differences in fat percentage and BMI, where the median was higher for girls. 
Table 4 - Comparison of differences in control and intervention groups: comparison of means (mean \pm d) and median (median (Q1; Q3)) (Steps 1 and 2) (n=79)

\begin{tabular}{|c|c|c|c|}
\hline \multirow[t]{2}{*}{ Variables } & \multicolumn{2}{|c|}{ Group } & \multirow[t]{2}{*}{ P-value } \\
\hline & Control & Intervention & \\
\hline Weight & $5.80 \pm 3.62$ & $3.62 \pm 2.60$ & $0,004 *$ \\
\hline Height in $\mathrm{cm}$ & $6,85(4,08 ; 9,30)$ & $5,00(3,85 ; 7,40)$ & 0,078 \\
\hline$\% \mathrm{GC}$ & $-2,00(-4,20 ; 0,88)$ & $-1,70(-4,70 ; 0,30)$ & 0,907 \\
\hline BMI & $1,16(0,34 ; 2,06)$ & $0,88(0,08 ; 1,55)$ & $0,001 * *$ \\
\hline Brachial and Sural triceps in $\mathrm{cm}$ & $-2,21(-4,88 ;-0,20)$ & $-3,05(-5,99 ;-0,10)$ & 0,571 \\
\hline Waist & $1,75(-0,13 ; 5,48)$ & $1,35(-0,25 ; 3,80)$ & 0,649 \\
\hline Hip & $1,50(-0,78 ; 3,63)$ & $0,50(-2,35 ; 3,25)$ & 0,069 \\
\hline Neck & $-0,05(-1,00 ; 0,50)$ & $0,00(-0,75 ; 0,30)$ & 0,882 \\
\hline Total cholesterol & $45,86(15,36 ; 66,46)$ & $-6,05(-16,31 ; 8,48)$ & $<0,001 * *$ \\
\hline Triglycerides & $30.61 \pm 42.88$ & $-15.66 \pm 46.18$ & $<0,001 *$ \\
\hline Glucose & $-17,38(-22,99 ;-11,48)$ & $9,81(-19,39 ; 16,86)$ & $0,002 * *$ \\
\hline Adiponectin & $8,44(-2,82 ; 17,01)$ & $-1,86(-13,45 ; 6,06)$ & $\mathbf{0 , 0 3 3} * *$ \\
\hline
\end{tabular}

$\% \mathrm{BF}=$ body fat; $\mathrm{BMI}=$ body mass index; *Student $\mathrm{t}$ test independent sample; **Man Whitney test. Source: Authors.

Table 5 - Comparison of differences in the boys x girls groups: comparison of means (mean \pm d) and medians (median (Q1; Q3)) (Steps 1 and 2) (n=79).

\begin{tabular}{|c|c|c|c|}
\hline \multirow[t]{2}{*}{ Variables } & \multicolumn{2}{|c|}{ Sex } & \multirow[t]{2}{*}{ P-value } \\
\hline & Male $n=40$ & Female $n=39$ & \\
\hline Weight & $4.35 \pm 3.32$ & $5.09 \pm 3.34$ & 0,338 \\
\hline$\% \mathrm{GC}$ & $-3,90(-8,15 ;-1,80)$ & $0,25(-2,05 ; 1,35)$ & $<0,001 *$ \\
\hline BMI & $0,49(-0,64 ; 1,16)$ & $0,91(0,05 ; 1,72)$ & $0,017 *$ \\
\hline Adiponectin & $3,88(-4,25 ; 13,19)$ & $3,68(-9,73 ; 11,82)$ & 0,735 \\
\hline
\end{tabular}

$\% \mathrm{BF}=$ body fat; $\mathrm{BMI}=$ body mass index; ${ }^{*}$ Man Whitney test. Source: Authors

Comparing the control group (CG) with the intervention group (GI), the children who presented a blood glucose value above $99 \mathrm{mg} / \mathrm{dl}$ (hyperglycemia) corresponded to $28.4 \%$ ( $\mathrm{n}=21,41.7 \%$ of CG and 15.8\% of GI) in Stage 1 and none in Step 2. In relation to the lipid profile, total cholesterol was above the reference value $(>170 \mathrm{mg} / \mathrm{dl})$ (hypercholesterolemia) to $5.5 \%$ ( $\mathrm{n}=4$, being $2.9 \%$ in CG and $7.9 \%$ in GI) of children in Step 1 and 16.7\% (n=12, 19.4\% of CG and 13.9\% in GI) for Step 2. For triglycerides, the values were altered $(>130 \mathrm{mg} / \mathrm{dl})$ (hypertriglyceridemia) in $13.7 \%$ ( $\mathrm{n}=10$, being $2.9 \%$ in $\mathrm{CG}$ and $23.7 \%$ in $\mathrm{GI}$ ) of children in Stage 1 and $11.1 \%(n=8,13.9 \%$ of $C G$ and $8.3 \%$ in GI) of children in Step 2 (Table 1).

The reductions in the sample number that occurred in some variables of the analyses performed were due to extreme values (outliers), hemolysis of the sample and child who refused to allow blood collection.

\section{Discussion}

In the comparison of the variables in the two moments of analysis in the intervention group (IG), an increase in weight, height and waist circumference was observed with statistical significance; expected due to the growth phase in which the children are. On the other hand, the measurements of the brachial and sural triceps, the percentage of body fat (\%BF) and triglycerides (TG) reduced during the follow-up. In the control group (CG), there was a significant increase in weight, height, body mass index (BMI), waist and hip circumferences, total cholesterol (TC) and TG. There was a reduction in the measurements of the brachial and sural triceps, \%BF and glycemia (GL). In the analysis of comparison of differences in the control and intervention groups, weight, BMI and adiponectin increased in the CG. The reductions in TC and TG were much higher and significant in IG 
and the reduction of GL was much higher in CG. In the comparison of the differences between the groups between boys and girls, only the reductions of \% BF and BMI were significant, where the reduction was higher in boys.

In reaction to adiponectin, in both groups there was a non-significant increase in adiponectin, but it was close to significance for the $\mathrm{CG}(\mathrm{p}=0.061)$. In $\mathrm{CG}$, GL significantly reduced and the increase in adiponectin was almost significant, because adiponectin acts favorably on the regulation of GL metabolism and there are reductions in adiponectin levels and its bioactivity in obese patients and/or with elevated GL, evidencing the inverse relationship between adiponectin and GL levels. In IG, no significant changes in adiponectin and GL levels were observed. Data suggest that for a change in the level of adiponectin, weight reduction should be greater than $10 \%$, because studies that did not generate alterations in adiponectin, present in common weight loss of less than $10 \%$ in visceral fat (Klempel et al., 2011).

If on the one hand, the literature indicates that the practice of physical exercise has been associated with a significant increase in adiponectin in children (Sirico et al., 2018; García-Hermoso et al., 2017; Jamurtas et al., 2015) on the other hand, several meta-analysis studies and systematic review, reported inconsistent results in the pediatric population, without elevation of adiponectin after physical exercise program (Jadhav et al., 2021; Bouassida et al., 2010; Simpson \& Singh, 2008; Direcnet, 2008; Kelly et al., 2007). In a meta-analysis studies that measured adiponectin levels after three months, four months and one year of intervention, with or without dietary or lifestyle modification, it was observed that physical exercise had no significant effect on adiponectin levels (Jadhav et al., 2021).

The effect of exercise on adiponectin has been inconsistent. The different reasons include health status, age, sex, disease, diet, type of exercise, duration and intensity of exercise, training volume and method of prescription (Taherkhani et al., 2020). But even with this variety of results found, the literature presents evidence that physical exercise exerts a protective effect against the reduction of serum adiponectin, because even if its concentrations do not increase, exercise prevents its reduction, which may be frequent in sedentary individuals prone to increased adiposity (Silva et al., 2011).

In the present study, it was observed that sedentary children, belonging to the CG, presented a significant increase in BMI. It was also observed that more children in the IG became eutrophic (8\%), demonstrating that even if the children submitted to the physical activity program did not present a reduction in BMI, it did not go up, as occurred in the CG. Another study also found no reduction in BMI with implementation of the physical exercise program for children (Liu et al., 2019).

When analyzing the \%BF, it is possible to see a good result of statistically significant reduction in IG and CG. The individuals included in the study did not present weight reduction, but this evidence does not exclude, however, a possible beneficial alteration that physical exercise may have exerted on body composition, such as increased lean mass or a non-increase in adipose mass, since they presented a reduction in \%BF. According to Kelley, Kelley \& Pate (2020), there is a lack of convincing evidence to suggest that there are real differences in interindividual response in relation to aerobic training and changes in fat mass and body fat percentage in overweight and obese children and teens.

Regarding the lipid profile, there was a significant reduction in TG in IG and a significant increase in CG in the comparison of the two moments of the study. For TC, in the CG there was a huge and significant increase. Evaluating the difference between TG and CT in the comparison of the groups, it was found that the reduction of these values was much greater and significant in the IG. Analyzing the results of TC and TG, it was evident that the parameters showed improvements with the physical exercise program, while the CG suffered very great worsening of these varables. A review study found that aerobic and resistance training improves body composition, lipid profile and metabolic and inflammatory status of obese children and teen $\mathrm{s}$ (Paes et al., 2015). Other studies with exercise intervention also found improvements in lipid profile (Soaresa et al., 2018; Militão et al., 2013; Bezerra et al., 2013; Santos et al., 2012; Tibana et al., 2012; Kelley et al., 2011; Jackson et al., 2010; Maslow et al., 2010; Cheng et al., 2007). 
This study presented some limitations, such as: non-identification of children's eating habits or measurements of other variables (psychic, social, economic, environmental, life habits, ethnic, clinical and biochemical), which could influence the program effect. It is believed that strategies for the involvement of relatives in the program should be prioritized in future research. But despite the limitations, the study has great clinical importance, because it is believed that the results here presented, if used by health professionals, will help in the guidance and planning of patients and parents about physical exercises and weight loss programs, reducing childhood obesity and comorbidities.

In summary, the present study showed that the practice of physical exercise did not increase adiponectin levels, but was responsible for a great improvement in the children lipid profile, while in the CG there was a great worsening of TC and TG. The intervention program did not help in reducing BMI, but both groups showed a reduction in \%BF, showing that both the practice of physical exercises and educational lectures were able to influence the reduction of adiposity.

\section{Conclusion}

In summary, the present study showed that the practice of physical exercise did not increase adiponectin levels, but was responsible for a great improvement in the children lipid profile, while in the CG there was a great worsening of TC and TG. The intervention program did not help in reducing BMI, but both groups showed a reduction in \%BF, showing that both the practice of physical exercises and educational lectures were able to influence the reduction of adiposity.

\section{References}

Bezerra, A.I.L.; Kanegusuku, H.; Prado, W.L.; et al. (2013). Efeito do exercício físico aeróbico e de força no perfil lipídico de seus praticantes: uma revisão sistemática. Rev. Bras. Ativ. Fis. e Saúde, 18(4), 399-400. DOI: 10.12820/rbafs.v.18n4p399

Bouassida, A.; Chamari, K.; Zaouali, M.; et al. (2010). Review on leptin and adiponectin responses and adaptations to acute and chronic exercise. Br. J. Sports. Med, 44, 620-630. DOI: 10.1136/ bjsm.2008.046151

Brasil. Ministério da Saúde. Sistema de Vigilância Alimentar e Nutricional - Relatórios Públicos. (2020). http://sisaps.saude.gov.br/sisvan/relatoriopublico/index Cheng, E.W.; Gregg, N.; de Rekeneire, D.E.; et al. (2007). Muscle-strengthening activity and its association with insulin sensitivity. Diabetes Care, 30(9), 22642270. DOI: 10.2337 / dc07-0372

Díaz, B.B.; Amaiz, M.L.; Picón, D.C.; et al. (2018). Adiponectina sérica en adultos normopeso, con sobrepeso u obesidad y su relación com el riesgo cardiovascular. Acta Bioquím Clín Latinoam, 52(1), 5-13.

DIRECNET - Diabetes Research in Children Network - Study Group. (2008). Adiponectin and catecholamine concentrations during acute exercise in children with type 1 diabetes. Pediatr. Diabetes, 9(3), 221-7. DOI: 10.1111/j.1399-5448.2008.00372.x

Freitas, A.E.; Oliveira, T.H.; Lacerda, D.R.; et al. (2007). Prevalência de obesidade e sobrepeso em escolares de 6 a 9 anos nas escolas públicas de Ouro PretoMG. Rev. Méd. Minas Gerais, 17(1), S91-S159. DOI: 10.5935/2238-3182.20130002

García-Hermoso, A.; Ceballos-Ceballos, R.J.M.; Poblete-Aro, C.E.; et al. (2017). Exercise, adipokines and pediatric obesity: a meta-analysis of randomized controlled trials. Int J Obes, 41, 475-482. DOI: 10.1038 / ijo.2016.230

Jackson, A.W.; Lee, D.C.; Sui, X.; et al. (2010). Muscular strength is inversely related to prevalence and incidence of obesity in adult men. Obesity (Silver Spring), 18(10), 1988-1995. DOI: 10.1038 / oby.2009.422

Jadhav, R.A.; Maiya, G.A.; Hombali, A.; et al. (2021). Effect of physical activity promotion on adiponectin, leptin and other inflammatory markers in prediabetes: a systematic review and meta-analysis of randomized controlled trials. Acta Diabetol, 58(4), 419-429. DOI: 10.1007 / s00592-020-01626-1

Jamurtas, A.Z.; Stavropoulos-Kalinoglou, A.; Koutsias, S.; et al. (2015). Adiponectin, Resistin, and Visfatin in Childhood Obesity and Exercise. Pediatr. Exerc. Sci, 27, 454-462. DOI: 10.1123 / pes.2014-0072

Kelley, G.A.; Kelley, K.S. \& Pate, R.R. (2020). Are there inter-individual differences in fat mass and percent body fat as a result of aerobic exercise training in overweight and obese children and adolescents? A meta-analytic perspective. Child. Obes, 16(5). DOI: 10.1089/chi.2020.0056.

Kelly, A.S.; Steinberger, J.; Olson, T.P.; et al. (2007). In the absence of weight loss, exercise training does not improve adipokines or oxidative stress in overweight children. Metabol. Clin. Experim, 56, 1005-1009. DOI: 10.1016/j.metabol.2007.03.009

Klempel, M.C. \& Varady, K.A. (2011). Reliability of leptin, but not adiponectin, as a biomarker for diet-induced weight loss in humans. Nutr. Rev, 69(3), 145154. DOI: 10.1111/j.1753-4887.2011.00373.x 
Research, Society and Development, v. 11, n. 3, e17811326429, 2022 (CC BY 4.0) | ISSN 2525-3409 | DOI: http://dx.doi.org/10.33448/rsd-v11i3.26429

Liaw, J.J.T. \& Peplow, P.V. (2016). Effects of Electroacupuncture on Pro-/Antiinflammatory Adipokines in Serum and Adipose Tissue in Lean and Diet-induced Obese Rats. J Acupunct Meridian Stud, 9(2), 65-72. DOI: 10.1016 / j.jams.2015.06.011

Liu, Z.; Li, Q.; Maddison, R.; Mhurchu, C.N.; et al. (2019). A School-Based Comprehensive Intervention for Childhood Obesity in China: A Cluster Randomized Controlled Trial. Child. Obes, 15(2). DOI: 10.1089 / chi.2018.0251

Martínez-Hernández, J.E.; Suárez-Cuenca, J.A.; Martínez-Meraz, M.; et al. (2021). Papel de la adiponectina en obesidad y diabetes tipo 2. Medicina interna de Méx, 35(3), 389-396. DOI: 10.24245/mim.v35i3.2448

Maslow, A.L.; Sui, X.; Colabianchi, N.; et al. (2010). Muscular strength and incident hypertension in normotensive and prehypertensive men. Med. Sci. Sports Exerc, 42(2), 288-295. DOI: 10.1249 / MSS.0b013e3181b2f0a4

Mendonça, E.; Ciane, R.; Canella, D.; et al. (2020). Panorama da obesidade em crianças e adolescentes. Instituto Desiderata, 2(2). https://desiderata.org.br/wp/wp-content/uploads/2019/11/DESIDERATA_PANORAMA-OBESIDADE_WEB_depoimentos.pdf

Militão, A.G.; Karnikowski, M.G.O.; da Silva, F.R.; et al. (2013). Effects of a recreational physical activity and healthy habits orientation program, using an illustrated diary, on the cardiovascular risk profile of overweight and obese schoolchildren: a pilot study in a public school in Brasilia, Federal District, Brazil. Diabetes Metab. Syndr. Obes, 6, 445-51. DOI: 10.2147 / DMSO.S52166

Onis, M.; Onyango, A.W.; Borghi, E.; et al. (2007). Development of a WHO growth reference for school-aged children and adolescents. Bull World Health Organ, 85, 660-7. DOI: 10.2471 / blt.07.043497

Paes, S.T.; Marins, J.C.B. \& Andreazzi, A.E. (2015). Metabolic effects of exercise on childhood obesity: a current view. Rev. Paul. Pediatr, 33(1), 122-129. DOI: $10.1016 /$ j.rpped.2014.11.002

Paim, M.B. \& Kovaleskib, D.F. (2020). Análise das diretrizes brasileiras de obesidade: patologização do corpo gordo, abordagem focada na perda de peso e gordofobia. Saúde Soc, 29(1), e190227. DOI: 10.1590/S0104-12902020190227

Romano, F. Adipocinas, obesidade e doenças crônicas. (2010). Atividade física adaptada e saúde. Luzimar Teixeira. [Internet]. http://www.luzimarteixeira.com.br/adipocinas-obesidade-e-doencas-cronicas/

Santos, D.M.; Pozzobon, A. \& Périco, E. (2012). Efeito de um programa de exercício físico na qualidade de vida, perfil lipídico e glicêmico de mulheres com risco de doenças cardiovasculares. Cad. Pedagog, 9(2), 173-184.

Silva, A.A.; Priore, S.E. \& Natali, A.J. (2011). Exercício físico e adipocinas: uma revisão dos efeitos do exercício regular. $R$. bras. Ci. e Mov, 19(4), 120-130.

Simpson, K.A. \& Singh, M.A.F. (2008). Effects of exercise on adiponectin: A systematic review obesity. Obesity, 16, 241-256. DOI: 10.1038 / oby.2007.53

Sirico, F.; Bianco, A.; D’alicandro, G.; et al. (2018). Effects of physical exercise on adiponectin, leptin, and inflammatory markers in childhood obesity: systematic review and meta-analysis. Child. Obes, 14(4), 207-217. DOI: 10.1089 / chi.2017.0269

Soaresa, B.T.; Amaral, L.V.R.; Cardozo, D.C.; et al. (2018). Efeito do exercício físico sobre a dislipidemia effect of physical exercise on dyslipidemia. Rev. Aten. Saúde, 16(58), 12-16. DOI: 10.13037/ras.vol16n58.5312

Taherkhani, S.; Suzuki, K. \& Castell, L. (2020). Uma breve visão geral das mudanças nas citocinas inflamatórias e estresse oxidativo em resposta à atividade física e suplementação com antioxidantes. Antioxidants, 9, 1-18. DOI: 10.1590/S1809-98232012000200018

Tibana, R.A.; Teixeira, T.G.; de Farias, D.L.; et al. (2012). Relação da circunferência do pescoço com a força muscular relativa e os fatores de risco cardiovascular em mulheres sedentárias. Einstein, 10(3), 329-334. DOI: 10.1590/S1679-45082012000300013

WHO - World Health Organization. Obesity and overweight. WHO. (2020). https://www.who.int/news-room/fact-sheets/detail/obesity-and-overweight 